\title{
Optimality of Tax Policy on the Basis of Comparative Analysis of Income Taxation
}

\author{
George Abuselidze ${ }^{1}$, Doctor of Economics, Professor
}

\begin{abstract}
This paper is to determine the optimality of taxation based on a comparative analysis of income taxation in developed and developing countries. In our opinion, the main idea of income tax should be the optimal distribution of tax literacy on the basis of a direct definition of income of taxpayers or progressive taxation.

The theoretical and methodological basis of the research is the main provisions of the market economy, classical and modern tax theories, legislative and regulatory acts of foreign countries. The main part of the empirical material is from 2002 to 2017. In the process of analysis of the actual material, together with the general scientific method of research, is used: Comparative and systemic analysis, analogy, statistical data monitoring and other methods. The comparative and systemic analysis will give us an opportunity to reveal and evaluate the ways of perfection. Analogy and comparative analysis is based on variables and features, such as the of income taxes structure, withdrawal rules, rates, tax base. Statistic concept tries to explain the named phenomena by the way of fundamental analyzing of the statistic data received resulted multiple statistic observation. Previous analyses of tax rates tend to support the hypothesis that Developed countries emphasize the importance of fairness, while developing countries are mainly focused on mobilizing budget revenues and lesser consideration of fair taxation principles, since the tax system performs a fiscal function more effectively than developing countries.
\end{abstract}

Keywords: Tax policy, income tax, tax burden, budget, well-being

\section{Introduction}

The correct fiscal policy carried by the state creates the basis for well-being of the country. The formation of the budget depends on the theoretical-methodological base of tax system operating in the country, which at the same time represents the basis for the optimal level of tax rates. None of the issues of state policy are as important as tax structure and level - these two factors define the possibilities and capabilities of funding important public programs, affects economic growth and development, poverty level, consumption level, reduction of inequality and other economic and social type decisions.

Issues concerning tax rates, in parallel with the socio-economic and political processes in the country, requires constant improvement and development. Accordingly, research of these issues and searching scientific innovations, studying foreign experience and analyzing should be conducted continuously. In the formation process of tax burden, it is important to consider psychological aspects in relations between taxpayer and tax authorities, define the possible response of taxpayers on some kind of taxes. All of this 
makes it even more attractive and more relevant to scientifically study and understand problems of tax system, problems related to the formation of tax forms.

Optimization of the tax system is the prior task of all states, since funding of necessary expenditure by government is depended of its smooth functioning. The economic basis for the formulation and development of the state is the financial sources that are mainly generated by taxes and payments in the state budget. The effective and efficient functioning of the country's economic system depends on the tax policy carried by state. Namely, the legislative regulation of taxation of individuals by income tax. The goal of any country is to set an optimal level of income tax rate, which on the one hand ensures tax revenues in budget and on the other hand perform the function of fairness function of taxes.

Recent evidence suggests that tax always is an actual issue in the public discussions, because it is an essential element of the system of economic relations and is so complicated without effectives in tax policy. Previous research has shown that the study of the optimization of taxable income taxes in the modern stage is not only researchers but also an important concern for practitioners. Author identifies that the severity of this tax is based on the income tax analysis and impacts the welfare of society. In addition, it is one of the major tax revenues for the budget, which is predictable, more or less accurate and dependent on the functioning of the state to fund the necessary expenditures. In our opinion that tax burden affects not only budget revenues, but economic activity, production capacity, price standards etc. Finally, all above affects socio-economic position of country (Abuselidze, 2013, p. 1451). The optimal determination of tax base tax base is an essential element of tax policy, as long as the obligation to pay is the most wider mass of taxpayer individuals (employees, individual entrepreneurs, etc.). Therefore, optimization of a taxable base with this tax is the main task for the state by considering the income of the population. In this paper, we examine the results of systematic and comparative analysis of tax systems and offer strategic recommendations with regard to the theory of optimal tax burden.

\section{Literature Review}

The fair distribution of the income tax burden has long been a central issue in policy making. A large academic literature has developed models of optimal tax theory to cast light on the problem of optimal taxation progressivity and proportionate. There is a large volume of published studies describing optimal tax policy.

According to an investigation by Bertotti and Modanese (2018) tax compliance plays an important role towards the overcoming of economic inequality for individuals who care for society. In contrast, authors concluded that from the point of view of selfish individuals, the probability of improving their own economic status is higher when evading.

According to Peñalosa and Turnovsky (2005), for developing countries, indirect taxation is the main source of government revenue, representing in some cases up to $80 \%$ of total tax receipts, while personal and corporate taxes never account for more than 25\%. By contrast, in OECD economies, personal and corporate income taxation provide over $40 \%$ of tax revenues, while indirect taxation is only $27 \%$. However, 
according to Pikkety and Saez (2013) most advanced economies in the OECD raise between $35 \%$ and $50 \%$ of national income (GNP net of capital depreciation) in taxes. Tax to GDP ratios in OECD countries are between $30 \%$ and $45 \%$ and the more economically meaningful tax to national income ratios between $35 \%$ and $50 \%$.

Smith (1950) and Ricardo (1821) pointed to the factors determining real addressees of tax burden in their works. Smith connected size of wages to elasticity of labor supply, but Ricardo developed the ideas related to reaction of demand and supply regarding change of price for different goods, i.e. he considered elasticity of demand and supply a reference point. These considerations underlie the modern views which explain the problems of shifting of tax burden.

According to Heady's (1993) "there are at least two good reasons for abandoning Adam Smith's principle of fairness: (1) keeping taxes proportional to income at all levels will cause great hardship for people at or below the poverty line and (2) as argued above, it should be utility rather than income that represents ability to pay" (p. 21).

The Mirrlees (1971) model of optimal income taxation captures the key efficiency-equity tradeoff issue of redistribution: the government has to rely on a distortionary nonlinear income tax to meet both its revenue requirements and redistribute income. General results about optimal tax schedules are fairly limited.

A study by Mirrlees (1971) and Abuselidze (2012) suggests that there is no gain from having marginal tax rates above $100 \%$ because nobody will choose to have such a rate at the margin. According to this concept, at critical values of taxation pressure $t=0$ and $t=1$ activeness drops to minimum; at $\mathrm{t}=0$ - because state will not have any revenues and won't be able to perform its economic functions, and at $\mathrm{t}=1$ - because at $100 \%$ taxation no one wishes to work out any legal revenues. We disagree with the Laffer-Keynes theory postulates, considering that introduction of optimal mean tax rates only is not able to increase economic activity, production capacity and mobilization of maximal tax revenue in the budget.

According to Oh (2017) When taxes are increased, there is the plus is that tax revenue can be used to fund important governmental spending (including things like the military, healthcare, or education) or to redistribute to the poor. But the minus is that taxes discourage people from working. There is an unavoidable tension between raising revenue and distorting taxpayer behavior.

The standard theory of optimal taxation posits that a tax system should be chosen to maximize a social welfare function subject to a set of constraints (Mankiw, Weinzierl, \& Yagan, 2009).

Dixit and Sandmo (1977) using the tools of optimal tax theory expressed the optimal linear income tax rate in terms of elasticity. The researchers (Kanbur, Paukkeri, Pirttilä, \& Tuomala, 2018) show that the linear income tax includes additional components that work toward lowering the marginal tax rate. Public good provision in the optimal tax framework under poverty minimization was shown to depend on the relative efficiency of public provision versus income transfers in generating poverty reductions. One particular avenue where public provision is useful is via its potentially beneficial impact on individuals' earnings capacity. Thus, public provision can be desirable even if its direct welfare effects were non-existent. Roberts (2000) uses a perturbation method, similar in 
spirit to what is done in the present paper, and obtains optimal non-linear income tax formulas expressed in terms of elasticities.

Author analyzed the case of utility functions with no income effects and noticed that the Mirrlees formula for optimal rates is considerably simpler in that case and could be expressed in terms of the labor supply elasticity (Diamond, 1998).

One of the more significant findings to emerge from this study is that the rates are determined on the one hand with correlation of a taxation pressure and budget revenues, and rates influence on macroeconomic balance and well-being.

\section{Comparative analysis of income taxation and problem formulation}

\subsection{The tax to GDP ratio}

Regardless of which theory of optimal taxation resonates, the tax rates have an important impact on people and determines how to live, where to work or invest. According to OECD data, all society members' activities described above based on theory of optimal taxation.

The allocation of income generated from the production process prevail by the salary of employees. It uses as a basis the GDP of the European Union member state by income and considered for $47.5 \%$ of GDP at current market prices in 2016. Although it consists $40.7 \%$ of GDP the share of gross operating surplus and mixed revenue.

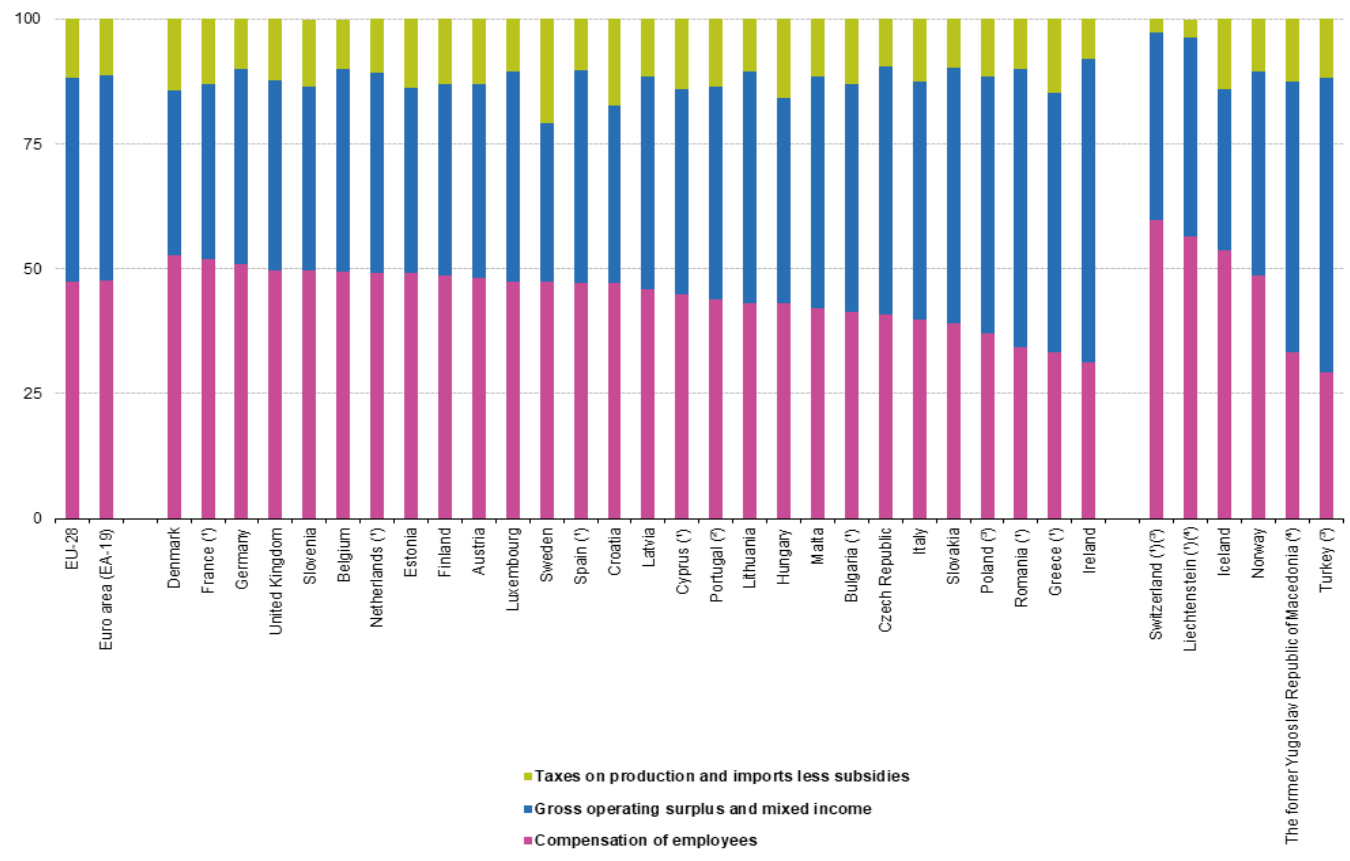

Source: Eurostat (online data code: nama_10_gdp)

Figure 1: Allocation of income at current market prices (\% share of GDP)

Source: Eurostat (2018). 
There are statistically significant, that the net social contributions consists $13.3 \%$ of GDP and current taxes on income, wealth, etc. - 13.0\%. All of them maintain equitable distribution. According to earlier research the share of current taxes on income, wealth, etc. becomes lower and was 12.1\% between 2007 and 2010. Contrary, it growth of 0.8 pp from 2010 to 2013 , remained the same from 2013 to 2015 and showed increase to $13.0 \%$ in 2016.

14

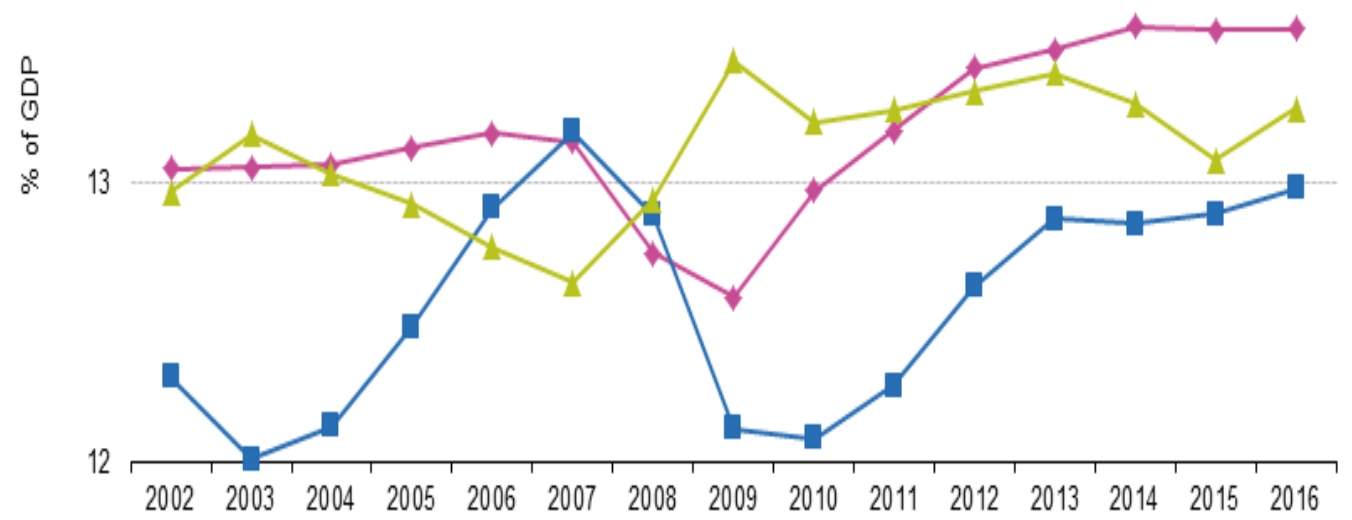

$\rightarrow$ Taxes on production and imports $\quad \rightarrow-$ Current taxes on income, wealth, etc. $\rightarrow-$ Net social contributions

Figure 2: Evolution of the main components of tax revenue in the EU, 2002-2016 (\% of GDP)

Source: Eurostat (2018).

In accordance with the present results (fig.2), previous studies have demonstrated that the share of direct taxes reduced more than GDP in 2008-2009. Also the reduce in direct taxes was very noticeable with comparison indirect taxes.

One of the issues that emerges from these findings is that during the crisis in 2008, income taxes and corporation's profits has decreased in 2008-2009. In 2009 it had a lower weight in the tax burden buy remained more intense than the individuals or household income's decrease.

The previous tax revenue statistics (fig.3) has shown that at the level of the EU, tax revenue of central government made up $52.7 \%$ of total tax and social contribution revenue. Considering all of evidence, it seems that the social provision funds subsector was quite important in terms of tax revenue in Slovakia (42.5\%), Czech Republic (43.1\%), Slovenia (38.7\%), Poland (37.0\%), Lithuania (40.3\%) and Georgia (23.47\%). This means the higher sensitivity of corporate profits to the economic climate and highlights the role of personal income taxes as stabilizers. 


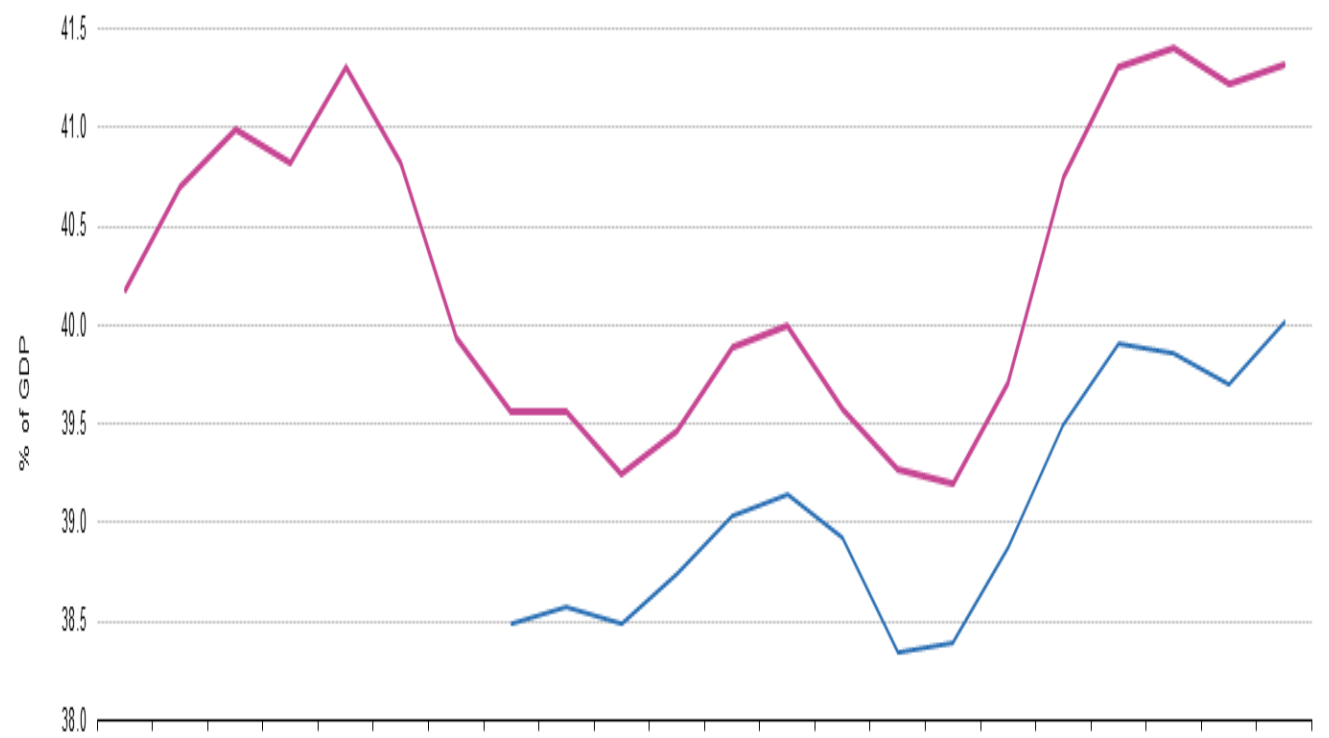

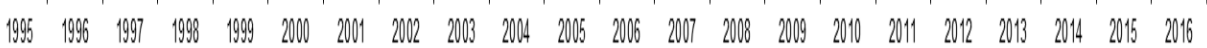

\section{-EU.88 Total revenue from taxes and social contibutions -EA.19 Total revenue from txaxes and social contributions}

Figure 3: Total revenue from taxes and social contributions, 1995-2016

Source: Eurostat (2018).

The level of public life is not defined by one particular criterion or indicator. The country's gross income may be high, but the main part of it may be distributed to the smallest number of population and beouse of that it is possible to generate inequality in the economy. It is generally known that if the Gini coefficient is close to 1, it means that inequality between the population in the country is relatively high, and the low value of the coefficient indicates that incomes in the country are equally distributed. As a rule, for countries with highly developed economies (Norway, Denmark, Slovak Republic, Slovenia, Czech Republic, Belgium, Austria, Poland, etc.) the social inequality index is much lower, and for the developing economies (Lithuania, Latvia, Turkey, Russia, Armenia, Azerbaijan, Tajikistan, etc.) the Gini index is relatively high. 
0.6
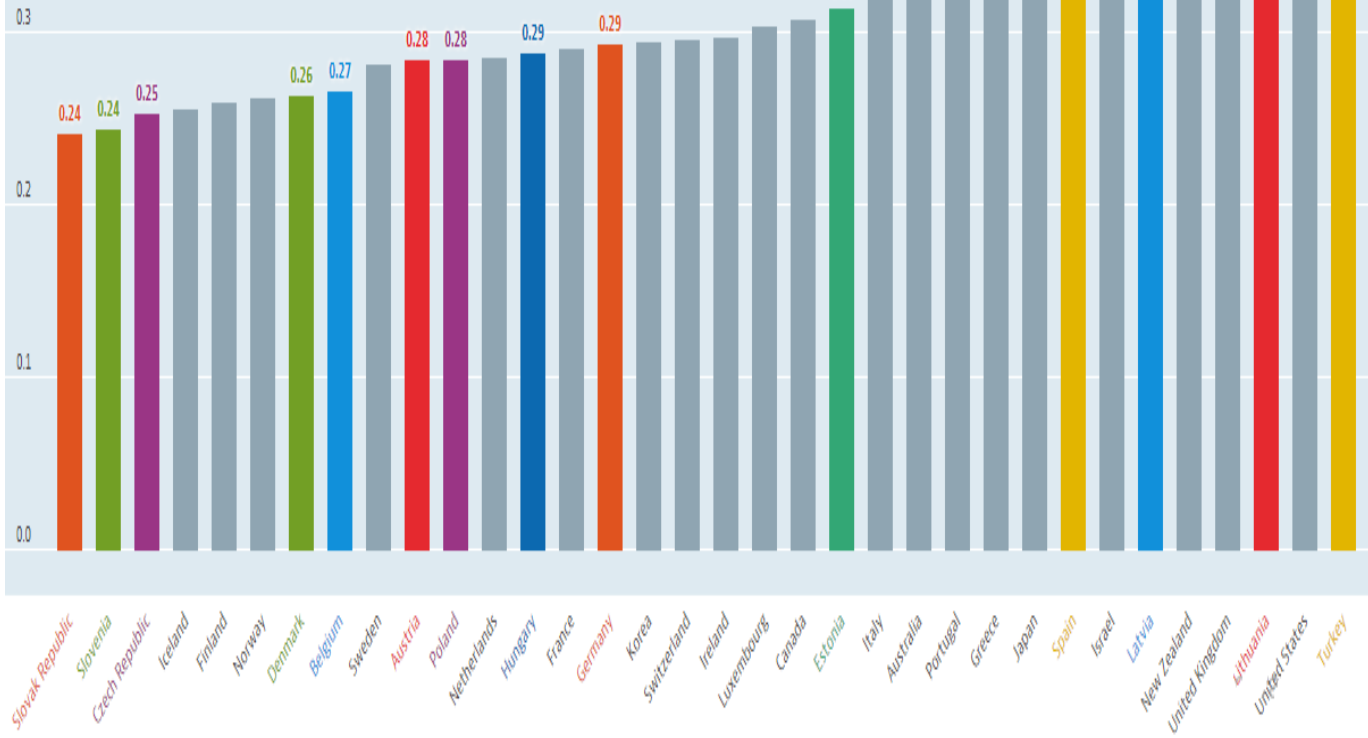

Figure 4: Gini ratios in OECD countries, income inequality

Source: OECD (2018).

The Gini Coefficient gathers some information on all individuals in a society and it considered as its strengths and weaknesses. Figure 4 presents the results obtained from the preliminary analysis, which show the difference between the Gini index using disposable income or gross income. The reasoning is based on that the Gini index can stay the same and distribution of income remains constant. At the same time, the Gini Index decrease with poverty and increase in the share of income (Piketty, et al. 2017).

It is widely known that one of the most important factors for the development of the country is the high level functioning of the tax system, however, with development, it is important to define the inequality between different layers of population. Recent studies Duncan and Sabirianova (2016) have shown that progressive taxation reduces inequality in observed income, but has a significantly smaller impact on actual inequality 
approximated by consumption based Gini index. In our opinion, income taxation should support the social function of the tax and support the country's wealth to distribute it equally.

\subsection{Characteristics income taxation}

Developed and developing countries' tax policy was evolving and developing various economic, political and social conditions. This in turn led to their similarities and differences (Tax Rates Around the World, 2018). They differ according to the types of taxes, their structure, withdrawal rules, rates, fiscal authority, tax base, taxes, and tax benefits at different levels of government. However, there are interesting features of the similarity. In particular, tax systems are based on such well-known principles of economic theory, such as: tax equality equity, fairness, effectiveness; Search for new ways to increase tax revenue; Taxes are taxed at the source of income of producers of goods, family farms or companies; Taxation depends on the family income or income of their members, the expenditures of final consumers, the incomes of retail traders, the gross income received from entrepreneurial activity, incomes from entrepreneurial activity, with the exception of losses, the wage fund, profits, wages, savings, dividends.

There are personal taxation based on individual rather than family in some countries (Georgia, Ukraine, Slovakia, Slovenia, Denmark, Lithuania and Polish). Amongst OECD countries there are requirement to file a joint return for family in France.

\subsubsection{Proportionate income taxation}

In Georgia an income tax payer shall be a resident natural person and a nonresident natural person earning income from a Georgian source. A natural person's taxable income shall be taxed at the rate of $20 \%$. As a result of renting out the residential space to an organization, legal or a natural person for residential purposes, the income received by a natural person who makes no deductions from this income and surplus income gained by a natural person from the provision of a residential apartment (house) and of the land attached to it, or from the provision of a vehicle, shall be taxed at the rate of 5\% (Ministry of Finance of Georgia, 2018).

In Lithuania (Sidlauskas, 2018), the PIT rate is a tax collected from individuals. Actual data, historical chart and calendar of releases - was last updated on August of 2019. The evidence suggests that the standard flat PIT rate is $15 \%$ (on the sale of property and on dividends). PIT at a 20\% rate is applied to income amounts not exceeding 104 thousand euros per fiscal year.

Hungary defines a flat PIT rate is $16 \%$. This does not necessarily mean that Hungarians have a lower overall tax burden, since it applies to all income. In addition, there is each spouse as a separate taxpayer and social insurance contributions are $18.5 \%$ of income for employees (National Tax and Customs Administration of Hungary, 2018). It should be noted that Romania and Bulgaria have a flat personal income tax (PIT) rate like Hungary (Barrios, et al. 2018).

According to the current tax rules of the Republic of Belarus (Tax code of the Republic of Belarus, 2017), they have personal income tax at a fixed rate: Income from employment - 9\%; individual entrepreneurs applying the General tax regime - 16\%; revenue from prizes received from gambling organizers is $-4 \%$. 
According to Tax code of Ukraine salary of the employee, revenue from foreign countries and etc. are taxed at 18\%. There are taxable as resident CIT payers (5\%), also non-residents, mutual investment funds, and non-payers of CIT and it made up 9\% (Tax code of Ukraine, 2014).

According to Heady's result (1993, pp.18-21) that taxes should be proportional to income. Instead, the objective is to minimize inequality, and in the absence of disincentive effects the inequality can be reduced to zero without any efficiency loss. None the less, the idea that the aim of tax policy is to eliminate all inequality has been used in attempts to discredit optimal tax theory and requires some comments.

The positive side of proportionate taxation is that proportional taxation contributes to economic growth, since the person is not punished for the fact that he has received more income. High rates of reductions in the lowest level can contribute to the increase of investments, which in turn increases the gross income and the taxable tax base, which, in turn, ensures economic stability.

The negative rate of proportional taxation may be considered that the uniform rate is unjustified burden for middle and low income persons. In this case, the tax burden comes from people with high incomes with low-income people who are less likely to pay, which violates one of the main principles of taxation - justice.

\subsubsection{Progressive income taxation}

The principle of justice can be regarded as a positive factor of progressive taxation (according to assessment of income revenue). In order to stimulate economic growth it is necessary to reduce the tax rate on medium and low class revenue, since they constitute the majority of the population, which will enable them to spend more income on the purchase of products and services. Everything is reflected in the growth of economic activity.

According to Schenk and Oldman (2006) PIT is a direct tax that is levied upon the income of a taxpayer. Most OECD countries employ different types of progressive income tax structures, in which tax rates grow with increasing income (Olsen, J., Kogler, C., Stark, J., \& Kirchler, E. 2017).

Latvia has taken a progressive PIT system from 1 January 2018 and the progressive rate applies based on the level of annual income: up to $€ 20$ thousand - 20\%; between $€ 20$ up to $€ 55$ thousand - $23 \%$; and any excess over $€ 55$ thousand - 31.4\%. Income from capital, excluding capital gains, including dividends, as of 2018, attracted a 10\% PIT. Dividends were paid out of the profits that had already been levied on the $15 \%$ corporate income $\operatorname{tax}$ (CIT). The recent correction to the PIT act lift the PIT dividend rate to $20 \%$ (Ministry of Finance Republic of Latvia, 2018). Although, where the company has already charged its earnings to CIT, there will be no further payment of PIT. This applies to Latvian, EU / EEA taxpaying companies and others, rather than companies with tax havens and micro business taxpayers. If you apply a PIT of $0 \%$ on dividends, $20 \%$ of the PIT or CIT paid in a foreign country will not require confirmation. At once, the corrections provide for a two-year transition, whereby the dividends paid on the balance sheet at December 31, 2017, can be distributed using a 10\% PIT.

The individual income tax rate in Slovakia is $19 \%$ up to $€ 35,022$ and up to $25 \%$ higher for this excess. Losses from different activities of individuals may be compensated by 
each other, but none of them can be recovered from employee income (Ministry of Finance of the Slovak republic, 2018).

Slovenia it is among the smallest countries in the European Union, but it has the highest tax rates amongst its fellow ex-Communist states. An individual's income is taxable, at a progressive rate of $16 \%$ - 50\% (tab.1).

Table 1: Individual Income Tax Rates of Slovenia

\begin{tabular}{|l|l|}
\hline Income & Tax rates \\
\hline $1-8,021$ & $16 \%$ \\
\hline $8,022-18,960$ & $27 \%$ \\
\hline $18,961-70,907$ & $41 \%$ \\
\hline 70,908 and over & $50 \%$ \\
\hline
\end{tabular}

Source: Ministry of Finance of the republic Slovenia

Slovenia's national government income taxes income from employment $(22 \%)$, from business activity (20\%), income from capital - dividends, interest and capital gains (25\%) but the longer the holding period, the lower the rate. By holding an investment for 20 years, an individual can avoid paying capital gains tax on that investment altogether.

In Poland has adopted a progressive PIT system, but there are two, and depends on the level of annual income: If a taxpayer earns less than PLN 85,528 during the calendar year - 18\%, and if more than PLN 85,528 - 32\% (Ministry of Finance Republic of Poland, 2018).

Spain has a progressive tax and tax rates are as follows: revenue up to $€ 12,450$ by $19 \%$; revenue from $€ 12,450$ to 20,200 by $24 \%$; revenue from $€ 20,200$ to 35,200 by $30 \%$; revenue between $€ 35,200-60,000$ is taxed by 37\%; more than $€ 60,000-45 \%$. Which means that higher-income individuals pay more taxes than lower-income individuals do (Spain accountants, 2018).

Germany levies a progressive tax rates like Spain. Its top rate is 45\% (Federal Ministry of Justice and Consumer Protection 2018), but Denmark's - 55.8\% and the average individual pays $45 \%$ though they have a developed economy in terms of GDP per capita and in nominal GDP per capita.

Austrian income tax law (2015) performed numerical analysis of tax rates from 2009 to 2015. In this period were exempted up to 11,000 euro annual incomes and were applied three progressively increasing tax rates $(36.5 \%, 43.2 \%$ and $50 \%)$. Also the highest rate, $50 \%$, was applied to incomes exceeding 60,000 euro annually. Based on the results described above, a tax reform in 2016 aimed at reducing the tax burden of low and medium income earners by introducing six tax rates $(25 \%, 35 \%, 42 \%, 48 \%, 50 \%$ and $55 \%$ ). In addition, research showed that the incomes of up to 11,000 euro are still exempted, but the highest tax rate was increased to 55\% for annual incomes exceeding 1,000,000 euro (Austrian income tax law, 2015).

As we can see from European states, Spain and Denmark are distinguished with high rates of taxes and it is used progressive tax method to eliminate inequality for both 
countries, however, because of a number of factors, it is not equally effective for both countries, Inequality rate in Spain is twice as high as in Denmark.

Therefore, the progressive taxes are an important source of elimination of poverty, unemployment and inequality, however, this does not mean that the fiscal mechanism in this country is equally beneficial and effective. Progressive taxes, as generally as other fiscal regulatory mechanisms, can have a positive economic effect for two main reasons: First of all, spending the flow of funds on human capital development, promotes economic growth, as far as 21 st century is based on a high level of knowledge and human capital.

The second positive side that is associated with the progressive tax rate is that the high level of inequality prevents economic growth. Therefore, it is important to assess the efficiency of progressive taxes and determine how efficiently and in what direction the money is spent. It is interesting in what direction are spent amounts transferred to the Spanish and Danish budget as a result of progressive taxes?

Table 3: Countries annual expenditure per student, by level of education OECD and partner countries, 2014 or latest available year

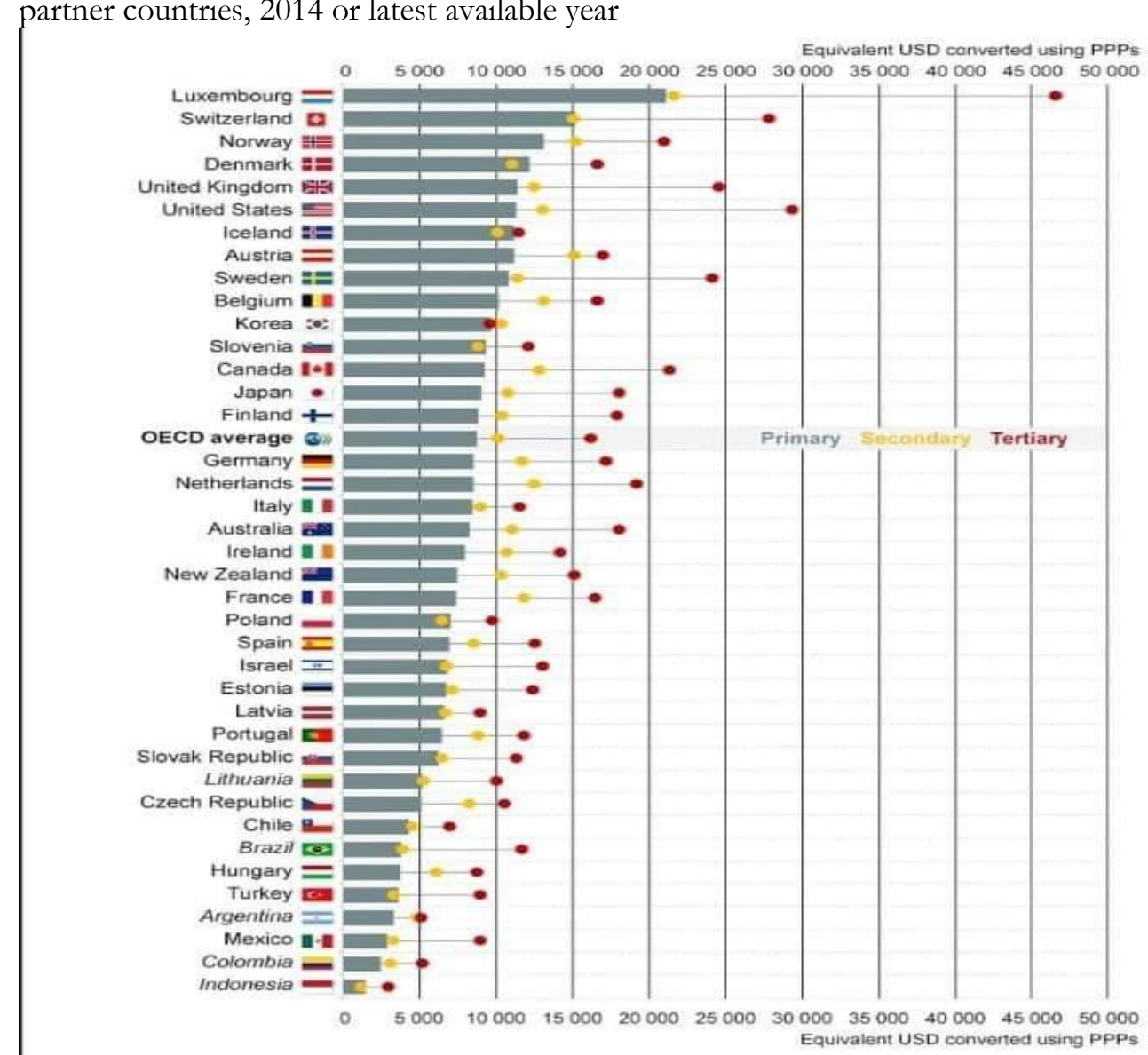

Source: OECD (2018). Education at a Glance 2017, p.173: OECD Indicators, Fig. B1.2. doi.org/10.1787/eag-2017-en. 
The main reason for the difference between the results is that, Denmark spends much more on education than Spain.

\subsubsection{Taxes on income, profits and capital gains (\% of revenue and current $L C U)$}

According to the report OECD of 2015, countries collected $34.1 \%$ of their tax revenue on income and profits (PIT and CIT taken together). PIT and CIT stay a major thing of income for the OECD in 10 countries to finance public spending, and nine of them - Poland, Latvia, Slovak Republic, Denmark, Belgium, Germany, Austria, Belarus, Ukraine, and Georgia - share of income tax increases in tax mix 35\%.

Within income and profit taxes, the share of PIT and CIT varies: personal income tax revenues account for $25 \%$ of total taxes, on average in 2015 , at about $30 \%$ in the 1980 s. About two percentage points of this reduction can be attributed to the OECD in Eastern Europe compared to OE, the average impact of relatively new participants, whose tax revenue data has only been available since the 1990s. These states have a relatively low income tax rates and high incomes from social security contributions, but this effect is only observed after 1990 data.

According to World Bank (2018) collection of development indicators, compiled from officially recognized sources taxes on income, profit and capital gains ( $\%$ of revenue and current LCU) as of 2015 in Latvia was 9.50\%; in Slovak Republic amounted 17.46\%; in Poland amounted 12.18\%; in Belgium was 35.07\%; in Germany was 16.81\%; in Denmark was 45.07\%; in Austria was 28.76\%; as of 2016 in Georgia Amounted to $35.36 \%$; in Belarus was 2.40\%; in Ukraine was $15.17 \%$ (fig. 5). 


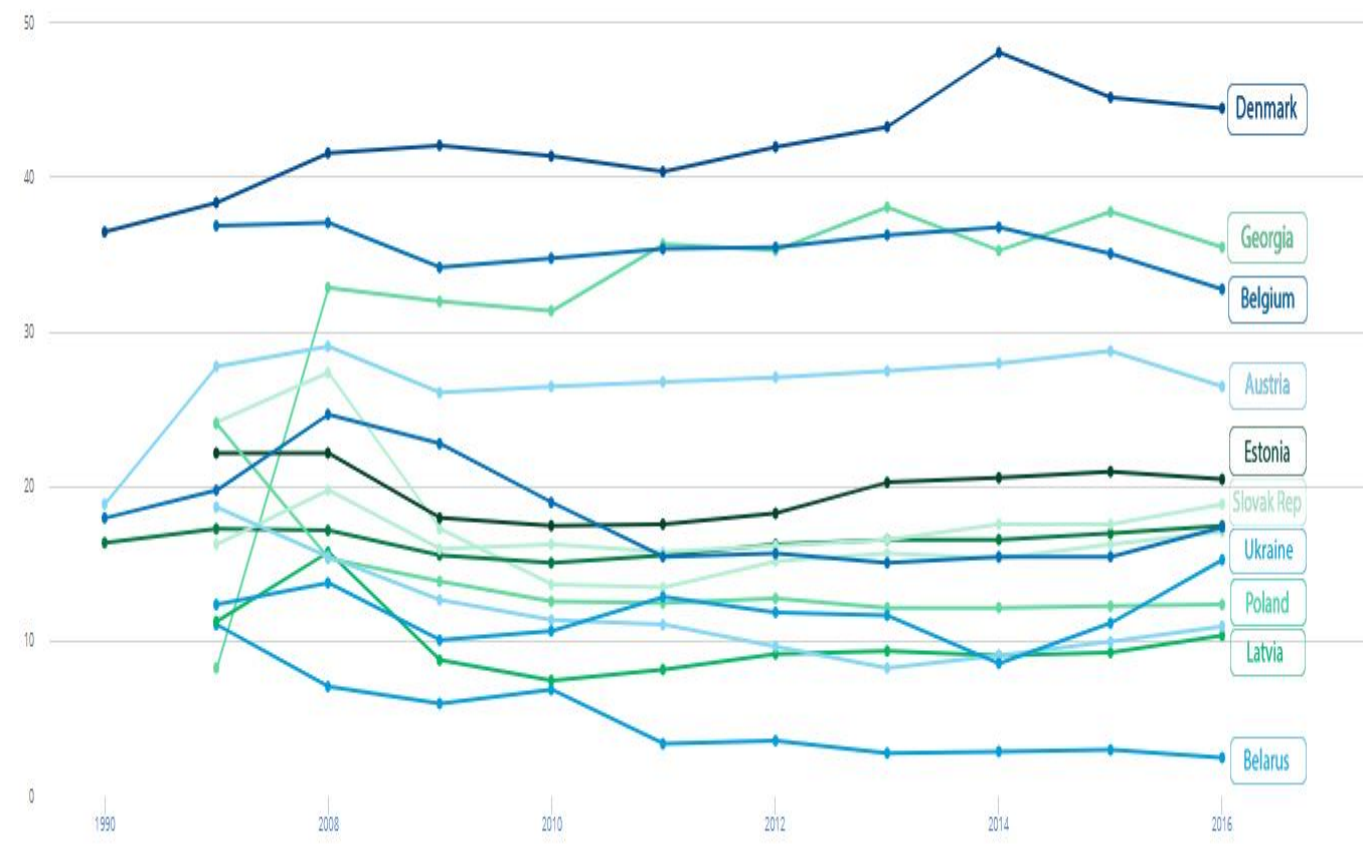

Source: Wortd Development hodicators

Figure 5: Taxes on income, profits and capital gains (\% of revenue)

Source: The World Bank Group (2018).

While as of 2016 in Lithuania was 630.065 Million LCU, in Hungary was 2.552 Trillion LCU, in Latvia was 1.102 Billion, in Poland was 75.236 Billion, in Slovak Republic was 5.69 Billion, in Belarus was 729,034 Million, in Slovenia was reported 1.683 Billion LCU in 2016; in Germany was reported at 155.795 Billion LCU in 2016; in Denmark was 360,116 Billion as of 2016; in Georgia was 3,034 Billion as of 2016 (fig.6). 


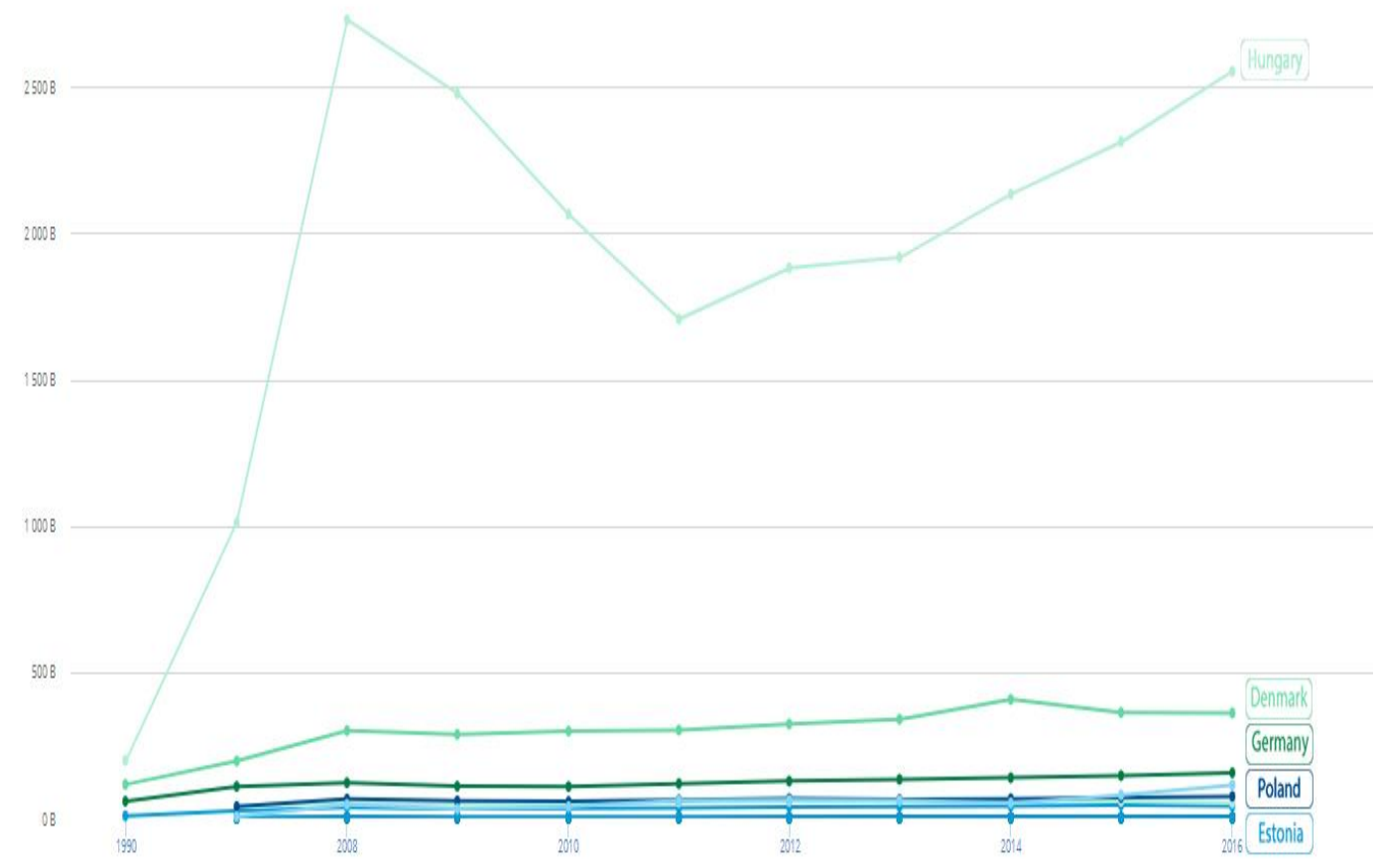

Source: World Development indicators

Figure 6: Taxes on income, profits and capital gains (current LCU)

Source: The World Bank Group (2018).

Previous research has established that comparative and systemic analysis of the world's economic situation and many-sided reasons of welfare crisis. One major theoretical issue that has dominated the field for many years is the absence of a well-grounded strategy leads to a further deterioration of the situation and a manifestation of the severity of fiscal policy. This leads to the fulfillment of the obligations undertaken by the budget, both in revenue points and in taxation of income.

To date there has been little agreement on what income tax rate shall be applied? One of the most significant current discussions is the question: Who should pay particular taxes for the principles of efficiency, equal rights and clarity - these are all questions a real government official and scientist are looking for in a timely, qualified answer, solution and realization.

The argument that income tax cuts raise growth is repeated so often that it is sometimes adopted as gospel (Gale \& Samwick, 2014). However, systematic and comparative studies tell a different and more complicated story - this mechanism is offset by the distributive concerns and in practice the optimal tax pressure for poverty minimization appear high. 
This research is a significant to analyze of progressivity. Namely, states with proportionate tax system states below in comparison with other EU member countries featuring progressive tax system.

\section{Problem Solution}

The main priority of any country shall include optimization of fiscal policy. Tax policy can increase the prosperity if it will increase economic activity in the country, resulting in a reduction of unemployment, improved labor and living conditions, forming a basic social security system and developing human capital (Abuselidze, 2018). In addition, optimization means solving two important assignments, that is maximizing budget revenues and taking into account the taxpayers solvency in setting tax rates. However, it should be borne in mind that even in the event of full access to the tax burden, serious tax distortions may occur. The topicality of income tax problems research is also driven by the sharp manifestation of negative trends in the effect of tax policy on the pace of economic activity.

Foreign scientists in this area have proven that taking into account the time factor is very essential how the average rate of total taxation changes, decreases or increases. A study by Alvaredo and Piketty (2008) suggests that in the most standard economic models of capital accumulation, the behavioral response tends to amplify (and not to counteract) the rise in tax rates. According to the Author (Abuselidze, 2015, p. 603) the plausible explanation for these findings is that any state always tries to increase taxes and such way provides growth of budget receipts and the probability of that event is given by:

$$
\operatorname{Lim} X_{n}=+\infty \text { and } \operatorname{Lim} Y_{n}=+\infty
$$

where $y_{n+1}>y_{n}, x_{n+1}>x_{n}$

In 2008, Alvaredo and Piketty demonstrated that raising tax rates imposed on very top incomes leads wealthy taxpayers to increase their consumption and to reduce their savings (Alvaredo and Piketty, 2008). The decrease of salaries will reduce the tax burden of the two parties if the total wage tax exceeds the corporate income tax rate. An employee avoids income tax (27 percent in 2014) and social security contributions (8.2 percent) and can agree to pay beyond his or her taxable market. The employer deducts tax due on uncertain payroll costs, which results in payroll taxes $(27 \%)$ but will benefit from pre-tax reimbursement costs and reduced social security contributions (14.1\%). Overall, the maximum marginal income tax rate is 47.2 percent higher than the corporate income tax rate of $27 \%$, implying that there are incentives on the margin to shift income from the former to the latter tax base (Bjørneby et al., 2018).

Income tax rates divided into the marginal rate and average rate. All of them rise as a subject of marginal tax rate in the progressive tax system. According to new tax plan, all employee from 35 to 45 charged increase in average tax rate $(5 \%)$ and in marginal tax rate $(3 \%)$.

Firstly, this feature greatly distorts the working choices of relatively productive agents. In addition, since these groups have little elasticity of participation and approximately zero participation, the government can increase its income at the expense of low efficiency. 
Usually, the average tax rate of a tax payer will be lower than the marginal tax rate. In a system with refundable tax credits, or income-tested welfare benefits, it is possible for marginal rates to fall as income rises, at lower levels of income.

Taxes are therefore differentiated to give the public good to the tax payer, in addition, such differentiation does not contradict to the count of the tax burden with formula (1). The present stage opinions of practitioner scientists regarding optimal tax burden are various. We share ideas Mirrlees (1971) and Karabarbounis (2011) and add our hypothesis $(2012 ; 2015)$ :

$$
X_{n}=\left\{a_{1}, a_{2}, a_{3}, a_{4}, a_{5} \cdots a_{n}\right\}
$$

If we note, that the optimal tax burden belongs to set $\mathrm{X}_{\mathrm{n}}$, we can express this dependence, as

$$
a \in X_{n} \text { and } X_{n} \rightarrow a_{3},\left(a_{3}=38.2 \%\right)
$$

are less than 100, what may be expressed, as

$$
\{x: x \in N, x<100\}
$$

Optimal income tax rate it may be provided with the formula:

$$
X(a)= \begin{cases}X h & \text { if } a \leq a_{3} \\ X l & \text { if } a>a_{3}\end{cases}
$$

The new tax code uses assets to differentiate labor income taxes between low and high income groups. We believe that the reform scenarios discussed below are sufficiently important to suit the particular circumstances and institutional characteristics of the countries shown in the research. The three scenarios discussed are as follows: lowincome groups with low assets pay higher labor income. Agents 1 and 2 of low-level asset ownership pay Xh and receive low net wages $(1-\mathrm{Xh})$. Although, their backup salaries are low enough that they are employed. Adjustment will occur only at the intense edge. Marginal workers 3 and 4 continue to work and pay lower taxes. Marginal 5 and 6 entrepreneurs enter the labor market in response to tax cuts. Under the new system, they receive a higher net salary $(1-\mathrm{Xl})$. Agents 7 and 8 are indifferent to this policy. Figure 7 illustrates the result. New tax policy increases employment. 


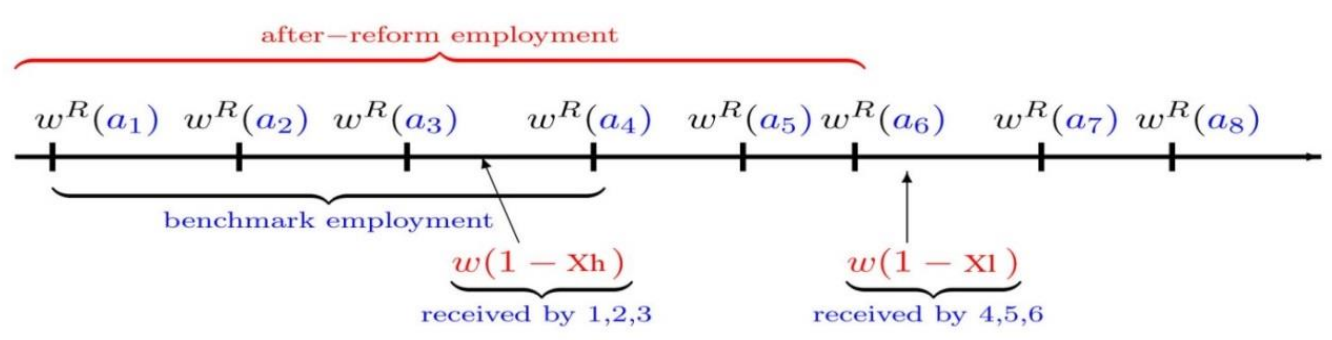

Figure 7: Effects of new tax system

Source: Authors' simulations based on the Karabarbounis model.

In our opinion, the optimal income tax rate is calculated as the ratio of the amount of tax paid to the amount of taxable income (i.e. shows the share of the taxpayer's income that is charged to the state budget). The aim of this research is to analyze the effect of tax burden on macro and micro economics. This study set out to investigate the usefulness of business activity as a way to distribute the fair unified tax burden to different economic actors, businessmen and consumers, to different groups of the population. Under the principle of horizontal equal taxation, persons with the same characteristics will be subject to the same tax burden; In contrast, under the principle of vertical equal taxation, the taxpayer pays taxes according to his position, but neither economic prosperity nor the ability to pay taxes constitute a basis for tax burden capital. Notwithstanding, all of them belong to the public contribution by a person determined by the importance of the economic production produced by that person. That is why taxes are differentiated by the taxpayer's privilege of public good. However, such distinction does not contradict the computation of the tax burden with the formula (1). This outcome of tax policy optimization is contrary to Heady (1993) and Sandmo (1990) who found that tax indicators fixed. We have demonstrated tax policy shall be formed such manner that provides progressiveness of tax rate and determination of tax burden generally with progressiveness towards the groups of economic activity.

It is known that the optimal tax plan sets average and marginal tax rates on the labor elasticity profile. Foremost, the plan markedly reduces tax rates for people close to retirement, and in older groups, wealth-rich agents experience greater tax cuts than their wealthier peers. This can be considered that the rich and the old are the most vulnerable to the economy. Also, the optimal policy is aimed at middle-income groups to increase their income. Finally, Weinzier (2010) noted that age-related taxation is an important instrument for redistribution. The optimal tax plan transfers resources to young and especially wealthy workers.

\section{Results of the survey}

The study of empirical material reveals first of all: that in the Romania, Bulgaria and Hungary have a personal income tax (PIT). It seems that only Hungary shows a 
similar level of redistribution with EU. It seems that EU member states are among the countries with lower distribution systems. So, PIT single rates in these countries described above were set at a progressive tax system with a minimum marginal tax rate, which previously acted as the case of Bulgaria, or even below this level, as in the case of Romania (16\% vs. 18\%) and Hungary (16\% vs. 17\%). However, despite the introduction of tax systems at first glance, the six countries have different PIT structures if they take into account different definitions of tax bases and the existence of tax credits and tax credits, which in many cases were introduced to compensate for negative redistribution. The impact of flat tax systems, the introduction of some de facto quality progress. Secondly, the inequality in the world has reached an unprecedented scale that has surpassed the grotesque inequality in the nineteenth century. The difficulty of the above problem indisputably makes it important to develop new financial mechanism, through which the reduction of inequality will be possible.

Based on the above, the results of the research can be formulated as follows: Optimization of the tax system is the prior task of all states, since funding of necessary expenditure by government is depended of its smooth functioning. In addition, optimization necessarily means solving two important tasks - maximizing revenue in the budget and taking into account the taxpayers' ability to pay while tax rate determination. In the paper, the tax system models were discussed on the example of developed/ developing countries. As a result of the research, it was proved that a number of developed countries (Slovak Republic, Slovenia, Czech Republic, Poland, etc.) use progressive taxes, since it increases the overall demand in the country's economy, in parallel with the reduction of inequality and poverty. Increase in overall demand in economy is due to the fact that the tax burden is low on middle and lower income representatives, i.e. those who are eager to consume and create demand, and it is high for reach people, whose taxes are in fact source for funding infrastructure, education, healthcare or other systems development.

The results obtained from our analysis concludes that introducing progressive tax reforms would have positive effects on redistribution and equity in all countries considered although to a varying extent depending on country-specific tax systems. In this respect the role played by existing tax expenditures is considered to be particularly relevant. The macroeconomic impact of the budget-neutral reforms appears to be positive for all countries in the medium-term. The findings show that lowering taxes on low-income individuals increases employment incentives, while increasing taxes on highincome individuals reduces employment rates. These anti-forces have a relatively modest impact on employment and GDP.

In the developed countries the economy of 21 st century is mainly based on the high level of knowledge and high rate of human capital. Therefore, if the funds received from progressive taxes are invested in education, there is a strong feedback between progressive taxes and economic growth. in addition, countries that use progressive taxes, the inequality index is noticeably low compared to other countries, although there is no direct correlation between progressive taxes and economic growth, progressive taxes and unemployment or poverty levels in the country. 


\section{Conclusion}

According to the study of empirical materials and the theoretical provisions, it is evident that in order to improve the social situation in the country, it is necessary to introduce progressive rates to ensure the distribution of revenue and fairness principles. The differentiation of tax rates according to revenue size is important. This is confirmed by the so called "psychological law" under which consumption does not increase in the proportion of revenue increase, since people create savings or address in financial speculative business, VAT of which is very low. Accordingly, in case of progressive taxes tax burden is higher on this layer (fiscal effect), that ensures human capital growth, budget revenue growth, infrastructure development, investments, decrease of unemployment, creating better management system, creation of healthy education and health systems, stimulating economy growth, etc. whereas low and average income people, who are part of the most spending community, the lack of tax burden increases the demand on the market, that in turn stimulates supply and production volume growth (economic effect). Therefore, progressive taxes are a powerful, proven and successful method to eliminate inequality and poverty, increase of budget revenues and economic development of the country.

It has been assumed that substantiated and alternative tax reforms would have a significant impact on equity and redistribution due to the reinforcement of progressive elements in the personal income tax system. And finally it would yield additional tax revenues.

The economic development in the 19th century is largely based on education and high indicator of human capital (e.g. Denmark), while high levels of inequality impede economic growth (e.g. Spain). Therefore, even though a number of European countries use progressive taxes, it is not equally successful and effective everywhere. Success of this method depends on what direction and how efficiently the tax revenue is spent. Like in Denmark, the introduction of a progressive tax may have positive consequences if received money will be invested in education and in increasing human capital indicator.

In our view, it is also important to divide taxes according to the regions' economic indicators and the level of development, since the regions of any country differ according to the level of revenue and taxing will affect the low-income people or region.

We think that after considering above mentioned recommendations the socio-economic situation of income taxpayers will significantly improve. As a result, we will be able to increase the volume of economic activity and production in the country, which is reflected in the achievement of the well-being of the country, region and every person.

\section{References}

1. Abuselidze, G. (2018). Optimal Fiscal Policy - Factors for the Formation of the Optimal Economic and Social Models. Journal of Business and Economics Review, 3(1), 18-27.

2. Abuselidze, G. (2015). Formation of Tax Policy in the Aspect of the Optimal Tax Burden. International Review of Management and Business Research, 4, 601-610.

3. Abuselidze, G. (2013). Optimal Tax Policy-Financial Crisis Overcoming Factor. Asian Economic and Financial Review, 3(11), 1451-1459. 
4. Abuselidze, G. (2012). The Influence of Optimal Tax burden on Economic Activity and Production Capacity. Intellectual Economics, 6(4), 493-503.

5. Alvaredo, F., \& Piketty, T. (2008). The Dynamics of Income Concentration over the Twentieth Century the Case of Advanced Economies. Retrieved from http://piketty.pse.ens.fr/fichiers/public/PIK2008DYNalvaredo.pdf

6. Austrian income tax law, $₫ 33$ Abs. 1 EStG 1988 (2015). Retrieved from: https://www.ris.bka.gv.at/Dokumente/Bundesnormen/NOR40174043/NOR40174043.pdf /.

7. Barrios, S., Ivaskaite-Tamosiune, V., Maftei, A., Narazani, E., \& Varga, J. (2018). Progressive tax reforms in flat tax countries (No. 2018-02). Joint Research Centre (Seville site).

8. Bertotti, M. L., \& Modanese, G. (2018). Mathematical models describing the effects of different tax evasion behaviors. Journal of Economic Interaction and Coordination, 13(2), 351-363.

9. Bjørneby, M., Alstadsæter, A., \& Telle, K. (2018). Collusive Tax Evasion by Employers and Employees: Evidence from a Randomized Field Experiment in Norway (No. 7381). CESifo Group Munich.

10. Diamond, P. (1998). Optimal Income Taxation: An Example with a U-Shaped Pattern of Optimal Marginal Tax Rates. American Economic Review, 88, 83-95.

11. Dixit, A. K., \& Sandmo, A. (1977). Some Simplified Formulae for Optimal Income Taxation. Scandinavian Journal of Economics, 79, 417-423.

12. Duncan, D., \& Sabirianova, P. K. (2016). Unequal inequalities: Do progressive taxes reduce income inequality?. International Tax and Public Finance, 23(4), 762-783.

13. Eurostat. (2018). Tax revenue statistics. Retrieved from: http://ec.europa.eu/eurostat/statisticsexplained/index.php/Main_Page /.

14. Federal Ministry of Justice and Consumer Protection. (2018). The Fiscal Code of Germany. Retrieved from: https://www.gesetze-im-internet.de/englisch_ao/index.html.

15. Federal Public Service Finance. (2018). General Administration of Taxes. Retrieved from: https://finance.belgium.be/en/about_fps/structure_and_services/general_administrations/taxati on.

16. Gale, W. G., \& Samwick, A. A. (2014). Effects of income tax changes on economic growth. Economic Studies. Retrieved from: https://www.brookings.edu/wpcontent/uploads/2016/06/09_Effects_Income_Tax_Changes_Economic_Growth_Gale_Samwic k.pdf

17. Heady, C. (1993). Optimal Taxation as a Guide to Tax Policy: A Survey. Fiscal Studies, 14(1), 15-41.

18. Kanbur, R., Paukkeri, T., Pirttilä, J., \& Tuomala, M. (2018). Optimal taxation and public provision for poverty reduction. International Tax and Public Finance. 25(1), 64-98.

19. Karabarbounis, M. (2011). Heterogeneity in Labor Supply Elasticity and Optimal Taxation. University of Rochester. Retrieved from: https://economicdynamics.org/meetpapers/2012/paper_655.pdf

20. Mankiw, N. G., Weinzierl, M., \& Yagan, D. (2009). Optimal taxation in theory and practice. Journal of Economic Perspectives, 23(4), 147-74.

21. Ministry of Finance of Georgia. (2018). Tax code of Georgia. Retrieved from: https://matsne.gov.ge/en/document/view/1043717.

22. Ministry of Finance Republic of Poland. (2018). The tax system of Poland. Retrieved from: http://www.finanse.mf.gov.pl/it/abc-of-taxes/tax-system-of-poland /.

23. Ministry of Finance of the republic Slovenia. (2018). Taxes and Custom Duties. Retrieved from: http://www.mf.gov.si/en/areas_of_work/taxes_and_customs/taxes_and_custom_duties/.

24. Ministry of Finance of the Slovak republic. (2018). Taxes, Customs and Accounting. Retrieved from: http://www.mfsr.sk/en/Default.aspx?CatID=52 / .

25. Ministry of Taxation. (2018). Taxation in Denmark. Retrieved from: http://www.skm.dk/english/taxation-in-denmark .

26. Ministry of Finance Republic of Latvia. (2018). Tax system in Latvia. Retrieved from: http://www.fm.gov.lv/en/s/taxes/.

27. Mirrlees, J. A. (1971). An Exploration in the Theory of Optimal Income Taxation. Review of Economic Studies, 38, 175-208.

28. National Tax and Customs Administration of Hungary (NTCA). (2018). Tax code of Hungary. Retrieved from: http://en.nav.gov.hu/taxation /.

29. Oh, J. S. (2017). Are Progressive Tax Rates Progressive Policy. New York University law review. 92(6), 1909-1976. 
30. Olsen, J., Kogler, C., Stark, J., \& Kirchler, E. (2017). Income tax versus value added tax: A mixedmethods comparison of social representations. Journal of Tax Administration, 3(2), 87-107.

31. OECD (2018). Social and Welfare Statistics: Income distribution. Retrieved from: https://data.oecd.org/inequality/income-inequality.htm

32. Piketty, T., Yang, L., \& Zucman, G. (2017). Capital Accumulation, Private Property and Rising Inequality in China, 1978-2015, NBER Working Paper no. 2338, National Bureau of Economic Research. Retrieved from: http://www.nber.org/papers/w23368.pdf.

33. Piketty, T., \& Saez, E. (2013). Optimal Labor Income Taxation. Handbook of Public Economics, 5, 391 474. doi.org/10.1016/B978-0-444-53759-1.00007-8.

34. Peñalosa C. G., \& Turnovsky S. J. (2005). Second-best optimal taxation of capital and labor in a developing economy. Journal of Public Economics 89 (2005), 1045-1074. doi:10.1016/j.jpubeco.2004.06.002

35. Ricardo, D. (1821). Principles of political economy and taxation. G. Bell. Retrieved from https://socialsciences.mcmaster.ca/econ/ugcm/3113/ricardo/Principles.pdf.

36. Roberts, K. (2000). A Reconsideration of the Optimal Income Tax in Hammond, P. J. and Myles, G. D. (eds.), Incentives and Organization: Papers in Honour of Sir James Mirrlees (Oxford: Oxford University Press).

37. Sidlauskas, A. (2018). Personal income tax. Retrieved from: http://taxguide.lt/personel-income-tax/ .

38. Schenk, A., \& Oldman, O. (2006). Value added tax: A comparative approach. Cambridge:

Cambridge University Press.

39. Smith, A. (1950). An Inquiry into the Nature and Causes of the Wealth of Nations, (1776). Methuen.

40. Spain Accountants. (2018). Personal Allowances for Spanish income tax. Retrieved from: https://www.spainaccountants.com/income-tax\#income_1.

41. Tax code of Ukraine. (2014). Customs Code of Ukraine, K.: SOE "SPC MinRD of Ukraine". Retrieved from: http://www.visnuk.com.ua/uploads/pdf/tax_code.pdf /.

42. Tax code of Belarus. (2017). Retrieved from: http://law.by/document/ guid $=3871 \& p 0=H k 0900071 \mathrm{e} /$.

43. Tax Rates Around the World. (2018). Key Data on World Taxes, Income Tax Rates, Tax Rates Comparison Table, Business \& Finance Worldwide (2018). Retrieved from: http://www.worldwide-tax.com/ .

44. Weinzierl, M. (2011). The Surprising Power of Age-Dependent Taxes. Review of Economic Studies, 4, 1490-1518. 
G. Abuselidze

(C) 2020 The Author. Journal Compilation $\quad$ C 2020 European Center of Sustainable Development. 